\title{
Insect antimicrobial peptides: isolation, separation and antimicrobial activity
}

\author{
E. K. Remizov, O.S. Larionova* \\ Saratov State Agrarian University, Teatralnaya square 1, Saratov, 410011, Russia
}

\begin{abstract}
In modern conditions of intensification of agriculture the industrial animal breeding involves the use of antibacterial drugs aimed at the prevention of infectious diseases. However, uncontrolled use of antibiotics leads to the selection of antibiotic-resistant strains, it should be noted that the treatment of diseases caused by these strains is difficult. Insect peptides have a barrier function and are able to protect the macroorganism from various pathogenic agents. In this study the original method of isolating protein fractions from the biomass of insect $G$. mellonella and M. domestica larvae was developed. The 19 protein fractions (PF) were obtained and their antimicrobial activity was studied as related to $S$. aureus ATCC 6538 (209-P), S. typhimurium 1626, C. albicans РКПГY -401/NCTC-885-653, B. cereus ATCC 10702. It was found that protein fractions No. 2, 2.3, 2.6, 3.4, 3.6 had antimicrobial activity as related to $S$. aureus ATCC 6538 (209-P); protein fractions No. 2, 2.6, 3.2, 3.6 inhibited the growth of S. typhimurium 1626; protein fractions No. 2, 2.3, 2.6, 3.3, 3.6 had an inhibiting effect on $C$. albicans РКПГY-401/NCTC-885-653, PF 2, 2.6, 3.2, 3.6, 3.7 had antimicrobial activity as related to B. cereus ATCC 10702.
\end{abstract}

\section{Introduction}

Nowadays there are research investigations related to the discovery of antimicrobial peptides (AMPs), which are effective in the treatment of infections caused by microorganisms also related to substances produced by insects. The reason for this is the evolutionary success that allows insects to occupy different habitats. Due to the lack of acquired immunity in invertebrates upon contact with pathogens, the protective effect can only be due to innate immunity. In addition, there are more than 30 million species of insects, that is, a huge source of resources for finding new substances for further use in medicine and veterinary [1-4].

Antimicrobial peptides in vivo have a detrimental effect on microorganisms not only due to direct action, but also due to the indirect killing through immunomodulatory effects. The increased production of AMP in the focus of inflammation causes the concentrations in such foci, which leads to the death of the microbial cell. In addition, in vivo AMPs of different classes and various antimicrobial substances have a synergistic antimicrobial effect [5]. According to some studies, the development of resistance in microorganisms to antimicrobial peptides in vitro is unlikely [6].

Furthermore, antimicrobial peptides do not adversely affect eukaryotic cells and can be used to treat animals as well as in animal feeding. The search for new alternative drugs to antibiotics in animal husbandry is primarily associated with the growing problem of antibiotic resistance [7].
Currently, the use of "classic" antibiotics to fight infectious diseases is due to their specific effect, the speed of exposure to the body of animals and the elimination of complications in the treatment of viral infections. However, such therapy does not always pass without consequences for the macroorganism and can lead to the selection of multi-resistant strains of pathogenic bacteria, a decrease in immunity and disruption of some organs [8]. Unlike classical antibiotics, antimicrobial peptides have a low probability of developing antibiotic resistance; however, they have antimicrobial activity against a wide range of bacteria, fungi and viruses, causing their rapid killing and have anti-inflammatory properties.

High antibacterial activity against different groups of microorganisms, including antibiotic-resistant strains, low probability of selection of strains resistant to AMP, makes them a promising drug agents for the design of new effective antimicrobial drugs in veterinary medicine [9].

\section{Materials and methods}

The method of isolation of water-soluble peptides from the biomass of G. mellonella and M. domestica larvae, included of homogenization of the larval biomass, extraction, repeated centrifugation, salting with ammonium sulfate and repeated dissolution was developed. The pellet was collected in a separate tube after each centrifugation and the supercharger was poured out. All the samples obtained after centrifugation were frozen for subsequent manipulations [10].

\footnotetext{
Corresponding author: larionova1@mail.ru
} 
The resulting fractions were analyzed and separated by high-performance liquid chromatography (HPLC). Separation and determination were performed by HPLC with a preliminary search for the optimal set of solvents and conditions for chromatography.

A small amount of phosphate buffer salt solution (FSB) was added to the samples to dissolve the precipitation before chromatographic separation and then the solution was injected into the chromatograph.

The following model was selected for highperformance liquid chromatography: BioSep S2000 $300 \times 2120 \mathrm{~mm}$. The separation was conducted with 0.1 M FSB solution as the eluent, the flow is $1 \mathrm{ml} / \mathrm{min}$, with a loop volume of $1575 \mu \mathrm{l}$, at a wavelength of $280 \mathrm{~nm}$. The analysis time for a single sample takes $60 \mathrm{~min}$. The protein content in the test samples was determined by the Lowry method [11].

The bovine albumin is used to construct the calibration curve. A new calibration graph was constructed for each newly prepared Folin reagent. The protein content of the analyzed fractions was determined by the Lowry colorometric method on the spectrophotometric equipment of the company "ShimadzuUV-1280" at a wavelength of $450 \mathrm{~nm}$. The molecular weight of the isolated peptides was determined by polyacrylamide gel electrophoresis (PAAG) in the presence of sodium dodecyl sulfate (SDS-Na) using a Helicon camera and a BIO-RAD power supply [12].

The antibacterial activity was determined according to the Methodological guidelines 4.2.1890-04 Determination of the sensitivity of microorganisms to antibacterial drugs. Methodological guidelines (MG 4.2.1890-04, 2004) [13].

The study of antibacterial activity was carried out by the macrotube method. The following cultures of microorganisms were used in the studies: S. aureus ATCC 6538 (209-P); S. typhimurium 1626, which were obtained from the Public Collection of Pathogenic Bacteria FGHI Russian Research Antiplague Institute «Microb», the Russian Agency for Health and Consumer Rights; B. cereus ATCC 10702, obtained from the Federal State Unitary Enterprise State-run Think Tank Genetics; C. albicans РКПГY -401/NCTC-885-653, E. coli 1027 obtained from the Laboratory «Russian Collection of Pathogenic Fungi» SFEI HPE NorthWestern State Medical University named after I. I. Mechnikov of the Ministry of Health of the Russian Federation.

\section{Results and discussion}

Thus, we obtained 19 protein fractions from the biomass of G. mellonella and M. domestica larvae by HPLC.

The column exit of protein fraction No. 2.1 was 5.24 $\%$ with a retention time of 2.15 minutes; No. $2.2-7.38$ $\%$ with a retention time of 14.27 minutes; No. 2.3 $16.12 \%$ with a retention time of 22.35 minutes; No. 2.4 $-68 \%$ with a retention time of 25.52 minutes; No.2.5 $0.65 \%$ with a retention time of 34.87 minutes; No. $2.6-$ $2.30 \%$ with a retention time of 43.46 minutes; No. 2.7 -
$0.31 \%$ with a retention time of 56.65 minutes (Figure 1, Table 1).

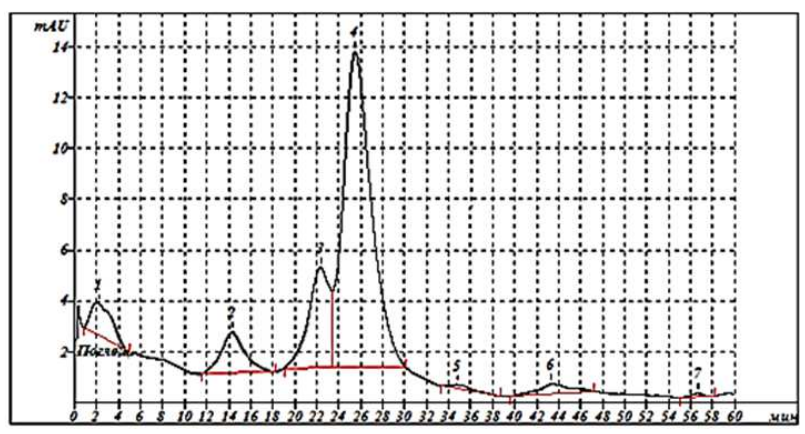

Fig. 1. Chromatogram protein fraction 2, isolated from biomass of G. mellonella larva

Table 1. Column exit of protein fraction, isolated from biomass of G. mellonella larva (Figure 1), \%

\begin{tabular}{|c|c|c|c|}
\hline No. & $\begin{array}{c}\text { tR - retention } \\
\text { time, min }\end{array}$ & $\begin{array}{c}\text { Area } \\
\text { response, } \\
\text { mAU } \\
\text { sec }\end{array}$ & Column exit, \% \\
\hline 2.1 & 2.15 & 170.32 & 5.24 \\
\hline 2.2 & 14.27 & 240.26 & 7.38 \\
\hline 2.3 & 22.35 & 524.57 & 16.12 \\
\hline 2.4 & 25.52 & 2212.25 & 68.00 \\
\hline 2.5 & 34.87 & 21.03 & 0.65 \\
\hline 2.6 & 43.46 & 74.91 & 2.30 \\
\hline 2.7 & 56.65 & 10.11 & 0.31 \\
\hline & Sum & 3253.44 & 100.00 \\
\hline
\end{tabular}

Table 2. Protein concentration of the obtained protein fractions (Figure 1), mg/ml

\begin{tabular}{|c|c|c|c|}
\hline No. & $\begin{array}{c}\text { tR }- \text { retention } \\
\text { time, min }\end{array}$ & $\begin{array}{c}\text { Sample } \\
\text { volume, } \\
\mathrm{ml}\end{array}$ & $\begin{array}{c}\text { Protein } \\
\text { concentration, } \\
\mathrm{mg} / \mathrm{ml}\end{array}$ \\
\hline 2.1 & 2.15 & 3 & $6.98 \pm 0.19$ \\
\hline 2.2 & 14.27 & 4 & $7.39 \pm 0.21$ \\
\hline 2.3 & 22.35 & 4 & $16.12 \pm 0.11$ \\
\hline 2.4 & 25.52 & 6 & $45.33 \pm 0.14$ \\
\hline 2.5 & 34.87 & 1 & $2.59 \pm 0.09$ \\
\hline 2.6 & 43.46 & 2 & $4.61 \pm 0.08$ \\
\hline 2.7 & 56.65 & 1 & $1.24 \pm 0.05$ \\
\hline
\end{tabular}

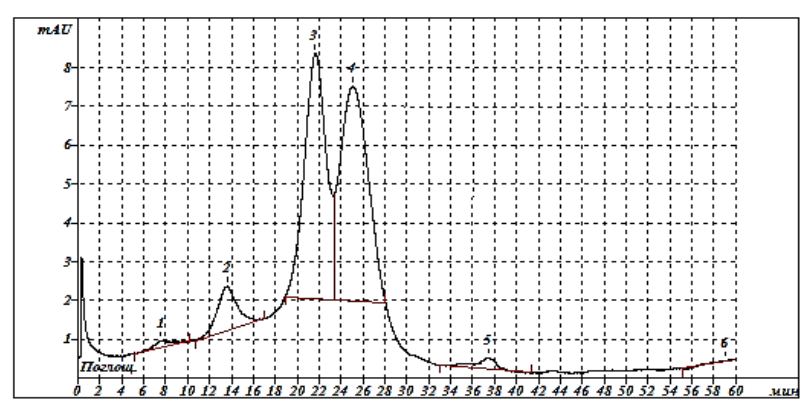

Fig. 2. Chromatogram protein fraction 3, isolated from biomass of G. mellonella larva 
The column exit of protein fraction 3.1 was $0.88 \%$ with a retention time of 7.63 minutes; No. 3.2-6.81\%, with a retention time of 13.58 minutes; No. 3.3-42.95\% with a retention time of 21.67 minutes; No. $3.4-47.43 \%$ with a retention time of 25.06 minutes; No. $3.5-1.91 \%$ with a retention time of 37.43 minutes; No. $3.6-0.01 \%$ with a retention time of 59 minutes (Figure 2, Table 3).

Table 3. Column exit of protein fraction, isolated from biomass of G. mellonella larva (Figure 2), \%

\begin{tabular}{|c|c|c|c|}
\hline No. & $\begin{array}{c}\text { tR }- \text { retention } \\
\text { time, min }\end{array}$ & $\begin{array}{c}\text { Area response, } \\
\text { mAU } \bullet \text { sec }\end{array}$ & $\begin{array}{c}\text { Column } \\
\text { exit, \% }\end{array}$ \\
\hline 3.1 & 7.63 & 18.10 & 0.88 \\
\hline 3.2 & 13.58 & 139.46 & 6.81 \\
\hline 3.3 & 21.67 & 879.51 & 42.95 \\
\hline 3.4 & 25.06 & 971.21 & 47.43 \\
\hline 3.5 & 37.43 & 39.11 & 1.91 \\
\hline 3.6 & 59.00 & 0.28 & 0.01 \\
\hline & Sum & 2047.67 & 100.00 \\
\hline
\end{tabular}

Table 4. Protein concentration of the obtained protein fractions (Figure 2), $\mathrm{mg} / \mathrm{ml}$

\begin{tabular}{|c|c|c|c|}
\hline No. & $\begin{array}{c}\text { tR - retention } \\
\text { time, min }\end{array}$ & $\begin{array}{c}\text { Sample } \\
\text { volume, } \\
\mathrm{ml}\end{array}$ & $\begin{array}{c}\text { Protein } \\
\text { concentration, } \\
\mathrm{mg} / \mathrm{ml}\end{array}$ \\
\hline 3.1 & 7.63 & 2 & $2.65 \pm 0.09$ \\
\hline 3.2 & 13.58 & 4 & $10.22 \pm 0.11$ \\
\hline 3.3 & 21.67 & 5 & $51.54 \pm 0.12$ \\
\hline 3.4 & 25.06 & 3 & $94.86 \pm 0.21$ \\
\hline 3.5 & 37.43 & 2 & $5.73 \pm 0.08$ \\
\hline 3.6 & 59 & 2 & $0.04 \pm 0.03$ \\
\hline
\end{tabular}

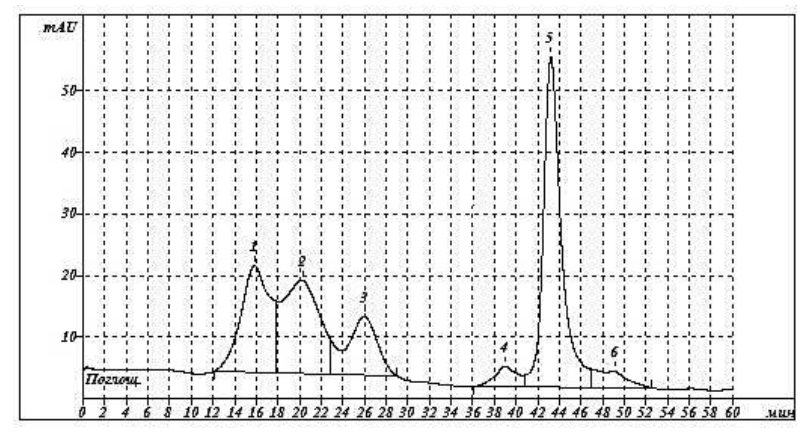

Fig. 3. Chromatogram protein fractions 1-6, isolated from biomass of $M$. domestica larva

The column exit of protein fraction No. 1 was 20.33 $\%$ with a retention time of 15.85 minutes; No. $2-22.43$ $\%$ with a retention time of 20.20 minutes; No. 3 $11.87 \%$ with a retention time of 25.98 minutes; No. $4-$ $2.99 \%$ with a retention time of 38.96 minutes; No. 5 $38.84 \%$ with a retention time of 43.23 minutes; No. $6-$ $3.54 \%$ with a retention time of 49.02 minutes (Figure 3 , Table 5).
Table 5. Column exit of protein fraction, isolated from biomass of M. domestica larva (Figure 3), \%

\begin{tabular}{|c|c|c|c|}
\hline No. & $\begin{array}{c}\mathrm{tR}- \\
\text { retention } \\
\text { time, min }\end{array}$ & $\begin{array}{c}\text { Area response, } \\
\mathrm{mAU} \bullet \mathrm{sec}\end{array}$ & $\begin{array}{c}\text { Column } \\
\text { exit, \% }\end{array}$ \\
\hline 1 & 15.85 & 3239.77 & 20.33 \\
\hline 2 & 20.20 & 3574.26 & 22.43 \\
\hline 3 & 25.98 & 1892.03 & 11.87 \\
\hline 4 & 38.96 & 476.09 & 2.99 \\
\hline 5 & 43.23 & 6188.91 & 38.84 \\
\hline 6 & 49.02 & 563.49 & 3.54 \\
\hline & Sum & 15934.55 & 100 \\
\hline
\end{tabular}

Table 6. Protein concentration of the obtained protein fractions (Figure 3), mg/ml

\begin{tabular}{|c|c|c|c|}
\hline No. & $\begin{array}{c}\text { tR - retention } \\
\text { time, min }\end{array}$ & $\begin{array}{c}\text { Sample } \\
\text { volume, } \\
\mathrm{ml}\end{array}$ & $\begin{array}{c}\text { Protein } \\
\text { concentration, } \\
\mathrm{mg} / \mathrm{ml}\end{array}$ \\
\hline 1 & 15.85 & 6 & $20.33 \pm 0.45$ \\
\hline 2 & 20.20 & 4 & $33.65 \pm 0.65$ \\
\hline 3 & 25.98 & 4 & $17.81 \pm 0.78$ \\
\hline 4 & 38.96 & 5 & $3.59 \pm 0.91$ \\
\hline 5 & 43.23 & 6 & $38.84 \pm 0.31$ \\
\hline 6 & 49.02 & 5 & $4.24 \pm 0.15$ \\
\hline
\end{tabular}

Then protein fractions were dialyzed after separation for 24 hours against $0.9 \%$ sodium chloride solution. When studying the molecular weight of the isolated peptides, it was found that it was in the range of 3.4-6 $\mathrm{kDa}$.

The antimicrobial activity of protein fractions No. 2.1-2.7; 3.1-3.7 isolated from the biomass of $G$. mellonella larvae and PF No. 1-6 isolated from the biomass of $M$. domestica as related to $S$. typhimurium 1626, S. aureus ATCC 6538 (209-P), C. albicans РКПГY -401/NCTC-885-653, B. cereus ATCC 10702 were determined by the macrotube method. The experiment was performed in three replications for each culture of microorganisms. The test tubes were placed in a thermostat at $37{ }^{\circ} \mathrm{C}$ for 24 hours. After the time had elapsed, the results were recorded.

Protein fractions 2.3 and 2.6 inhibit the growth of the S. aureus ATCC 6538 (209-P), and PF 2.6 inhibit the growth of $S$. typhimurium 1626 was found. Protein fractions 2.3 and 2.6 have activity as related to $C$. albicans РКПГY -401/NCTC-885-653, 2.6 - B. cereus ATCC 10702. Antimicrobial activity of PF $2.1 ; 2.2 ; 2.4$, 2.5 and 2.7 was not detected (Table 7).

Then, the antimicrobial activity of PF 3.1-3.7 was studied by the same method. It was found that PF 3.4 and 3.6 have antimicrobial activity as related to $S$. aureus ATCC 6538 (209-P). Protein fractions 3.2 and 3.6 inhibit the growth of the S. typhimurium 1626, PF 3.3 and 3.6 - C. albicans РКПГY-401/NCTC-885-653. Protein fractions $3.2,3.6$, and 3.7 exhibit antimicrobial 
activity as related to the B. cereus ATCC 10702 (Table 8).

Table 7. Antimicrobial activity of protein fraction No. $2.1-2.7$ (G. mellonella)

\begin{tabular}{|c|c|c|c|c|}
\hline \multirow{4}{*}{ Protein } & \multicolumn{4}{|c|}{ Strains of microorganisms } \\
\cline { 2 - 5 } fractions & S. & S. & C. & B. \\
& ATCC & typhimuri & albicans & cereus \\
& 6538 & um 1626 & PКПГY- & ATCC \\
& $(209-\mathrm{P})$ & & $401 / \mathrm{NCT}$ & 10702 \\
& & & C-885- & \\
\hline 2.1 & - & - & - & - \\
\hline 2.2 & - & - & - & - \\
\hline 2.3 & + & - & + & - \\
\hline 2.4 & - & - & - & - \\
\hline 2.5 & - & - & - & - \\
\hline 2.6 & + & + & + & + \\
\hline 2.7 & - & - & - & - \\
\hline
\end{tabular}

Notes - '+' - transparent broth (no microbial growth);

'-' - cloudy broth or there is a precipitate (microbial growth).

Table 8. Antimicrobial activity of protein fractions No. 3.1 3.7 (G. mellonella)

\begin{tabular}{|c|c|c|c|c|}
\hline \multirow[b]{2}{*}{$\begin{array}{l}\text { Protein } \\
\text { fractions }\end{array}$} & \multicolumn{4}{|c|}{ Strains of microorganisms } \\
\hline & $\begin{array}{c}S . \\
\text { aureus } \\
\text { ATCC } \\
6538 \\
(209-\mathrm{P})\end{array}$ & $\begin{array}{c}S \\
\text { typhimuriu } \\
m 1626\end{array}$ & $\begin{array}{c}C . \\
\text { albicans } \\
\text { РКПГY- } \\
\text { 401/NCT } \\
\text { C-885- } \\
653\end{array}$ & $\begin{array}{c}\text { B. } \\
\text { cereus } \\
\text { ATCC } \\
10702\end{array}$ \\
\hline 3.1 & - & - & - & - \\
\hline 3.2 & - & + & - & + \\
\hline 3.3 & - & - & + & - \\
\hline 3.4 & + & - & - & - \\
\hline 3.5 & - & - & - & - \\
\hline 3.6 & + & + & + & + \\
\hline 3.7 & $\begin{array}{llll}- & \\
\end{array}$ & - & - & + \\
\hline
\end{tabular}

Notes - ' + ' - transparent broth (no microbial growth); '-' - cloudy broth or there is a precipitate (microbial growth).

Table 9. Antimicrobial activity of protein fraction 1-6, isolated from biomass of $M$. domestica larva

\begin{tabular}{|c|c|c|c|c|}
\hline \multirow{4}{*}{} & \multicolumn{4}{|c|}{ Strains of microorganisms } \\
\cline { 2 - 5 } Protein & S. & & & \\
aureus & ATCC & S. & C. albicans & B. \\
fractions & 6538 & typhimurium & PKПГY- & cereus \\
& $(209-$ & 1626 & 401/NCTC- & ATCC \\
& P) & & $885-653$ & 10702 \\
\hline 1 & - & - & - & - \\
\hline 2 & + & + & + & + \\
\hline 3 & - & - & - & - \\
\hline 4 & - & - & - & - \\
\hline 5 & - & - & - & - \\
\hline 6 & - & - & - & - \\
\hline
\end{tabular}

Notes - '+' - transparent broth (no microbial growth); '-' cloudy broth or there is a precipitate (microbial growth).
The antimicrobial activity of protein fractions 1-6 isolated from the biomass of $M$. domestica larvae was determined by a macrotube method (Table 9). It was found that PF 2 had antimicrobial activity as related to $S$. aureus ATCC 6538 (209-P), S. typhimurium 1626, C. albicans РКПГY-401/NCTC-885-653, B. cereus ATCC 10702.

\section{Conclusions}

Our studies allowed us to develop an original method for isolating protein fractions from the biomass of insect larvae including homogenization; extraction; centrifugation; salting out with ammonium sulfate; dissolution; salting out with ammonium sulfate, and to work out an experimental technique for the separation of protein fractions in the course of high performance liquid chromatography. The chromatographic conditions were selected: BioSep S2000 300x2120 mm. The separation was conducted with $0.1 \mathrm{M}$ FSB solution as the eluent; the flow is $1 \mathrm{ml} / \mathrm{min}$, with a loop volume of $1575 \mu \mathrm{l}$, at a wavelength of $280 \mathrm{~nm}$. The analysis time for a single sample takes $60 \mathrm{~min}$.

As a result of studying the antimicrobial activity by the macrotube method, it was found that protein fractions No. 2.3 and 2.6 isolated from the biomass of $G$. mellonella larvae inhibit the growth of $S$. aureus strain ATCC 6538 (209-P), PF No. 2.6 - S. typhimurium 1626. Protein fractions No. 2.3 and 2.6 inhibit the growth of the $C$. albicans РКПГУ -401 / NCTC-885-653, No. 2.6 B. cereus ATCC 10702. Antimicrobial activity of PF No. $2.1 ; 2.2 ; 2.4 ; 2.5$ and 2.7 were not identified.

When studying the antimicrobial activity of protein fractions 3.1-3.7 isolated from the biomass of $G$. mellonella larvae, it was revealed that PF 3.4 and 3.6 have antimicrobial activity against the $S$. aureus ATCC 6538 (209-P). Protein fractions 3.2 and 3.6 inhibit the growth of $S$. typhimurium 1626, PF 3.3 and $3.6-C$. albicans РКПГY-401 / NCTC-885-653. Protein fractions 3.2, 3.6, and 3.7 exhibit antimicrobial activity in relation to the $B$. cereus strain ATCC 10702. The study of the antimicrobial activity of the protein fraction 2 isolated from the biomass of M. domestica larvae showed an antimicrobial activity in relation to $S$. aureus ATCC 6538 (209-P), S. typhimurium 1626, C. albicans РКПГУ -401 / NCTC-885-653, B. cereus АТСС 10702.

Research work on the isolation of the most promising AMPs can become a prerequisite for the development of highly effective antimicrobial drugs. In addition, it will help to solve the problem of disruption of microbiocenoses of living organisms, will contribute to the treatment of diseases caused by antibiotic-resistant strains and can be used to prevent diseases of various etiologies [14].

\section{References}

1. T. Ganz, Nat. Rev. Immunol., 3 (2003)

2. B. Peters, M.E. Shirtliff, M.A. Jabra-Rizk, PLoS Patho., 6 (2010) 
3. M-L. Clausen, T. Agner, Curr. Probl. Dermatol., 49 (2016)

4. E. Mylonakis, L. Podsiadlowski, M. Muhammed, Philos. Trans. R. Soc. Lond. B. Biol. Sci. (2016)

5. T. Rosen, J. Drugs Dermatol., 10 (2011)

6. V. Machado, J. Gelinski, C. M. Baratto, E. M. Borges, A. Vânia Vicente, M. F. Marian, Ind. J. of Pharm. Sci. (2020)

7. J.P. Powers, M. Morgan, L. Goosney, Antimicrob. Agents Chemother., 50(4) (2006)

8. G. Wang, B. Mishra, K. Lau, T. Lushnikova, R. Golla, X. Wang, Pharmaceuticals, 8, (2015)

9. S. Chernysh, N. Gordya, T. Suborova, PLoS One, $10(2015)$

10. L.S. Krylova, B.I. Drevko, E.A. Faust, E.K. Remizov, K.Yu. Smirnova, YA.B. Drevko, M.A. Borodina, T.S. Osina, O.S. Larionova,
Composition of antimicrobial peptides obtained from Musca domestica larvae and method of its preparation. Patent RU 2714128 C1, 12.02.2020. Application No. 2018142602 04.12.2018.

11. O.H. Lowry, N.J. Rosebrough, A.L. Farr, J. Biol. Chem., 193 (1951)

12. H. Schagger, G. von Jagow, Anal. Biochem., 166 (1987)

13. MG 4.2.1890-04. Determination of the sensitivity of microorganisms to antibacterial drugs. Methodological guidelines. Introduction. 2004-0304. (Moscow: Federal Center for State Sanitary and Epidemiological Surveillance of the Ministry of Health of the Rus. Fed., 2004)

14. L.S. Krylova, Ye.K. Remizov, K.Yu. Smirnova, O.S. Larionova, Current Issues of Vet. Biol., 4(44) (2019) 